\title{
Heimilislækningar - ný viðfangsefni byggð á sígildum kjarna
}

20. Norræna ping heimilislækna var haldið í Reykjavík í júní s.l. Fagfélög norrænna heimilislækna hafa staðið fyrir útgáfu vísindatímarits, Scandinavian Journal of Primary Health Care, frá árinu 1982. Í samvinnu við fræðasvið heimilislækna hafa félögin staðið fyrir heimilislæknapingum annað hvert ár frá árinu 1979. Раð hefur pví komið í hlut Félags íslenskra heimilislækna í samvinnu við fræðasvið heimilislæknisfræðinnar við Háskóla Íslands að halda pingin á 10 ára fresti, síðast í júní síðastliðnum. Pátttakendur voru tæplega 1.500, sem er metpátttaka, en pingið var haldið í Hörpu dagana 14. - 16. júní.

Pema pingsins var: „FROM THE CORE - Changes and Challenges in Primary Care“. Til pingsins var boðið 7 fyrirlesurum sem fluttu sína kjarnafyrirlestra, kynntar voru rúmlega 300 rannsóknir frá tæplega 30 pjóðlöndum auk pess sem haldnar voru fjölmargar vinnustofur og umræðufundir.

Heimilislæknar standa frammi fyrir afar ögrandi framtíðarverkefnum. Einstaklingum með fjölsjúkdóma fer fjölgandi, sem og peim sem eru á fjöllyfjameðferð, á sama tíma og rætt er um ýmiss konar skimanir sem geta oft á tíðum orkað tvímælis. Lífsstílstengdir sjúkdómar eins og offita og vaxandi fjöldi einstaklinga sem greinast með sykursýki verða viðfangsefni heimilislækna og reyndar pjóðfélagsins í heild í náinni framtíð. Rauði práðurinn á pessu norræna pingi var umræða um ofangreinda pætti ásamt ofgreiningum, oflækningum og ómarkvissri notkun heilbrigðiskerfisins.

Grunnstoðir heimilislæknisfræðinnar eru í föstum skorðum. Kjarnaatriðin, með samfellu og persónulegri pjónustu, eru sígild, svo og gott aðgengi að gæðapjónustu sem mætir pörfum einstaklinga og nútímasamfélags. Hins vegar eru ýmis atriði sem kalla á nýja nálgun heimilislækna pegar kemur að nýjum verkefnum á 21. öldinni. Heimilislæknar verða að taka meiri pátt í og hafa áhrif á skipulag heilbrigðiskerfisins, peir eru oft í betri stöðu en flestir aðrir til að átta sig á hvar heilbrigðispjónustan virkar vel og hvar parf að gera betur. Par af leiðandi er mikilvægt að peir verði virkari í umræðu og leggi sitt af mörkum við stefnumótun heilbrigðiskerfisins.

Mikilvægi félagslegra pátta eins og atvinnu og menntunar fyrir heilsufar var talsvert til umræðu á pinginu. Ennfremur var fjallað talsvert um pann ójöfnuð sem víða viðgengst hvað varðar aðgengi að heilbrigðispjónustu.

„Að rannsaka heilbrigt fólk of mikið og sinna síður peim sem raunverulega eru veikir er slæm heilbrigðispjónusta sem hefur neikvæð áhrif bæði á pá sem eru sjúkir og purfa meðferð en ekki síður á hina sem eru heilbrigðir", sagði Margaret McCartney, heimilislæknir frá Skotlandi. ${ }^{1}$ Hún fjallaði ennfremur um s.k. iðnaðarlækningar par sem læknum er gert að merkja við fyrirfram ákveðin atriði sem pó hafa ekki endilega með parfir sjúklingsins að gera. Oft á tíðum leiðir petta fyrirkomulag til pess að framkvæmdar eru ákveðnar rannsóknir sem gagnast skjólstæðingunum lítið eða ekkert.

Ómarkviss og of mikil notkun lyfja var talsvert rædd á pinginu og ljóst að heimilislæknar vilja vera í fararbroddi pegar kemur að markvissri notkun á lyfjum og rannsóknum pannig að fjármagn nýtist sem best án pess að slakað sé á gæðum pjónustunnar. Gagnrýnin hugsun og leit að haldgóðum, traustum gögnum um gagnsemi ákveðinna meðferða og rannsókna eru lykilatriði í viðleitni nútíma heimilislækninga til að ná pessum markmiðum.

Peter Vedsted, prófessor í heimilislækningum í Árósum í Danmörku, fjallaði um hlutverk heimilislækna og heilsugæslu í greiningu krabbameina. Hann lagði áherslu á nauðsyn pess að greina æxlin snemma og pá staðreynd að flestar greiningar á krabbameinum hæfust í heilsugæslunni. Hann brýndi heimilislækna til að halda vöku sinni og vera á varðbergi gagnvart einkennum illkynja sjúkdóma.

Að afloknu pessu fjölmennasta norræna heimilislæknapingi sem haldið hefur verið hingað til er ljóst að mikill hugur er í norrænum heimilislæknum. Pingið einkenndist af frábærum kjarnafyrirlestrum sem snertu ýmsar áskoranir nútíma heimilislækninga, kynningu á fjölbreyttu vísindastarfi og samheldni norrænna heimilislækna.

Með öldrun pjóða, notkun fleiri lyfja, fjölgun sjúklinga með langvinna sjúkdóma og fjölsjúkdóma er pörfin fyrir vel skipulagða og vel mannaða heilsugæslu gríðarlega mikilvæg. Til pess að аð pessi grunnpjónusta standi undir nafni purfa heilbrigðisyfirvöld á Íslandi að átta sig á mikilvægi pess að allir landsmenn hafi sinn heimilislækni og að ekki ríki sá ójöfnuður í pjónustu sem blasir við í dag.

Ping sem pessi gefa pátttakendum veganesti og hvatningu til að halda áfram gæðapróun og vísindastarfi en er ennfremur hvatning til að beita sér gagnvart ráðamönnum varðandi uppbyggingu og eflingu heilsugæslunnar.

1. http://www.nordicgp2017.is/ 